\title{
Factors affecting milking speed in Murciano-Granadina breed goats
}

\author{
E. Blasco, ${ }^{*}$ E. A. Gomez, ${ }^{*}$ C. Vicente, $†$ G. Vidal,ł and C. Peris $\S^{1}$ \\ *Centro de Tecnología Animal - IVIA, Apartado 187, 12400 Segorbe, Castellón, Spain \\ †Asociación de Ganaderos de Caprino de Raza Murciano-Granadina de la Comunidad Valenciana (AMURVAL), Calle Santísima Trinidad 1, \\ 46460 Silla, Valencia, Spain \\ $\ddagger$ Center for Animal Disease Modeling and Surveillance, Department of Medicine and Epidemiology, University of California, Davis 95616 \\ §Institut de Ciència i Tecnologia Animal - UPV, Camí de Vera s/n, 46020 València, Spain
}

\begin{abstract}
Milk flow during the first minute of milking was analyzed using data from 1,132 Murciano-Granadina breed goats belonging to 17 herds. During the individual lactations, 2 test days were scheduled for recording several milk flow traits, total milk, milk composition (fat and protein percentages), and somatic cell count. Average lag time from teatcup attachment to arrival of milk at the milk claw (T0) was $4.9 \mathrm{~s}$ and at the milk meter (T1) was $15.8 \mathrm{~s}$. Average milk flow after $30 \mathrm{~s}$ (MF0.5) was $0.29 \mathrm{~kg} / 30 \mathrm{~s}(0$ to $1.1 \mathrm{~kg} / 30 \mathrm{~s})$ and milk flow at 60 $\mathrm{s}$ or milking speed (MF1) was $0.67 \mathrm{~kg} / \mathrm{min}$ (0.1 to 2.1 $\mathrm{kg} / \mathrm{min}$ ). Repeatabilities of T0, T1, MF0.5, and MF1 were $0.45,0.58,0.62$, and 0.68 , respectively. The MF1 showed high phenotypic correlation with T1 $(-0.63)$ and MF0.5 (0.90), medium values with T0 $(-0.42)$ and total milk (0.22), and very low values $(-0.04$ to -0.12 ) with fat, protein, and somatic cell count. We found no differences between flows during the first 3 lactations, with a reduction as the lactation number increased. Months in milk since parturition affected MF1, being highest in the first $3 \mathrm{mo}(0.67-0.71 \mathrm{~kg} /$ min) and decreasing until the end of lactation $(0.58 \mathrm{~kg} /$ min). The effect of herd-test day was significant for all traits. Inclusion of all these effects for the analysis of milk flow traits is considered necessary.
\end{abstract}

Key words: milk flow, dairy goat, milking time, milk yield

\section{INTRODUCTION}

A large amount of working time on dairy goat farms is spent milking the animals (up to $55 \%$ of the total time; Marnet et al., 2005). To this end, farmers express an interest in reducing the time given over to milking, which could then be spent on other activities, such as cheese manufacturing and distribution or increasing the

Received January 8, 2016.

Accepted August 8, 2016.

${ }^{1}$ Corresponding author: cperis@dca.upv.es herd size. The time spent on milking depends on the number of milking sessions daily (1 or 2 in goats) and the hourly performance of milkers (goats milked per man and hour). In turn, this latter aspect is influenced by several factors related to the animals' ability for milking, the milking machine and parlor, the milking routine, and skill of the operators (Manzur et al., 2012; Bueso-Ródenas et al., 2014; Fernández et al., 2015). The animal's milkability conditions the time spent extracting its milk from the udder, which in turn is related on one hand with those udder features affecting the speed at which the different milking operations are carried out (teatcup attachment, machine stripping, and frequency of slipping or falling teatcups) and, on the other, the milk production and flow during machine milking. In this sense, milking speed is defined as the amount of milk produced by the animal in the first minute of milking (Ilahi et al., 1998). This trait is highly relevant and was found to be closely correlated with maximum milk flow (0.92), with average flow during milking (0.85), and with average flow during milk emission (0.85) in Alpine breed goats (Ilahi et al., 1999). In goat livestock, milk flow is considered to depend mainly upon anatomical and physiological teat characteristics (Marnet and McKusick, 2001; Marnet et al., 2005). Moreover, for the same animal, the milk flow tends to increase along with the quantity of milk present in the mammary gland (Peris et al., 1996; Komara and Marnet, 2009) due to the higher intramammary pressure. However, in small ruminants the presence of ejection reflex has no decisive effect on milk flow, unlike what occurs in dairy cattle (Bruckmaier et al., 1994; Marnet and McKusick, 2001).

In France, studies were carried out in Saanen and Alpine breeds on phenotypic variability and the estimation of genetic parameters for several milk flow-related traits (latency time, first minute milk flow, maximum and average machine milk flow, and total milking time). Results showed that milk flow presents a high degree of variability in both breeds (Ilahi et al., 1999; Marnet et al., 2005) and a major gene may be affecting this trait (Ricordeau et al., 1990), which would explain 
up to $60 \%$ of the genetic variance (Ilahi et al., 2000). Furthermore, the estimated heritability (from 0.42 to 0.65; Ilahi et al., 1999, 2000; Palhière et al., 2014) and repeatability values $(0.71-0.82$; Ilahi et al., 1998, 1999) for milk flow in the first minute were high, indicating that this trait could be subject to direct selection. The aim would be to increase the animals' milk flow and try to ensure that it is as uniform as possible to facilitate the milking routine and avoid over-milking. Nevertheless, excessively high flows may not be desirable, as studies in cattle have reported a positive relation with mastitis rates (Grindal and Hillerton, 1991) and SCC (Rupp and Boichard, 1999).

Spain is second among European countries in goat milk production (FAO, 2013), most of which is obtained from local breeds. Among the Spanish dairy goat breeds, the Murciano-Granadina stands out as the largest on record (500,000 animals; MURCIGRAN, 2015); however, little information is available for this breed on milking speed-related traits, nor have its genetic parameters been estimated. Only a few works are available, carried out on experimental farms using a small number of animals and, on occasion, with low production output at milking (Peris et al., 1996; Manzur et al., 2012). Therefore, to get a better estimate of the milk flow in the Murciano-Granadina goat population, it seems appropriate to record these variables in a sample that includes a large number of commercial farms and animals.

The aim of our study was to describe several milking speed-related traits in the Murciano-Granadina goat breed in greater depth, as well as their relation with other important factors for milk payment (production, composition, and SCC).

\section{MATERIALS AND METHODS}

This work was carried out on 17 livestock farms of the Murciano-Granadina Goat Breed Livestock Farmers' Association of the Valencia Community (AMURVAL), where official milk recording took place every $42 \mathrm{~d}$. On the majority of farms (13) the system was intensive, with animals permanently stabled, whereas on the rest of the farms some livestock were let out to graze for a few hours a day. Herd sizes varied from 100 to 2,000 goats, the average size being 390 animals. All the farms practiced once-daily machine milking, with similar milking parameters (vacuum level 40-42 $\mathrm{kPa}$, pulsation rate $90 \mathrm{pulse} / \mathrm{min}$, and pulsation ratio of $60 \%$ ) and the same milking routine (including machine stripping).

The experimental design proposed consisted of recording the milking speed traits twice in the same lactation. Monitoring was performed in females born by $\mathrm{AI}$ on the 17 farms cited, in their dams, which had been inseminated, and in their paternal grand-dams (dams of sires from the Murciano-Granadina breed genetic improvement program insemination center in Segorbe, Spain). All animals were fitted with a plastic bracelet on the hind leg to simplify identification when making the records (at the same time as the official milk recording was carried out). In total, 2,146 records on 1,132 goats were obtained in the period from 2007 to 2014. The number of records sampled per farm varied from 7 to 298 .

Milking speed traits were recorded using a stopwatch and the milk meter used in the official milk recording (WB Mini-Test meter, Tru-Test, Mineral Wells, TX). The recorded traits were

- T0: time (s) from attachment of teatcups to arrival of milk at the milk claw;

- T1: time (s) from attachment of teatcups to arrival of milk at the milk meter;

- MF0.5: milk yield $(\mathrm{kg})$ recorded in the milk meter $30 \mathrm{~s}$ after appearance of milk in the claw (T0); and

- MF1: milk yield $(\mathrm{kg})$ recorded in the milk meter $60 \mathrm{~s}$ after appearance of milk in the claw (T0).

Additionally, the total milk (TM, $\mathrm{kg}$ ) in the milk meter was recorded. Once milking was completed, milk samples were taken from each animal. The samples were kept refrigerated for transport to the laboratory and $0.15 \mathrm{~mL}$ of azidiol per sample was added as a preservative to prevent bacterial development. Milk composition (fat and protein percentages) was analyzed with a MilkoScan FT6000 (Foss Electric, Hillerød, Denmark) and the SCC was obtained using a Fossomatic 5000 (FossElectric).

Milking speed traits, TM, fat and protein percentages, and $\log _{10}$ SCC were statistically analyzed using a repeatability model. The effect of every goat over its records was considered as random. Farm-test day (142 levels, at least 7 data per level), lactation number (6 levels: 1, 2, 3, 4, 5, and $\geq 6$ ), and lactation stage (months in milk since parturition, 8 levels) were included as fixed effects. Phenotypic correlations were estimated.

\section{RESULTS}

Table 1 shows descriptive analyses of studied variables. The average values (SD) for T0 and T1 were 4.9 (4.0) and 15.8 (10.0) s, respectively, with minimum and maximum values separated by 48 and $88 \mathrm{~s}$ respectively. Mean value for MF1 was $0.67(0.33) \mathrm{kg} / \mathrm{min}$, varying widely between 0.1 and $2.1 \mathrm{~kg} / \mathrm{min}$. Mean value for MF0.5 was lower at $0.29(0.19) \mathrm{kg} / 30 \mathrm{~s}$ and its frequen- 
10104

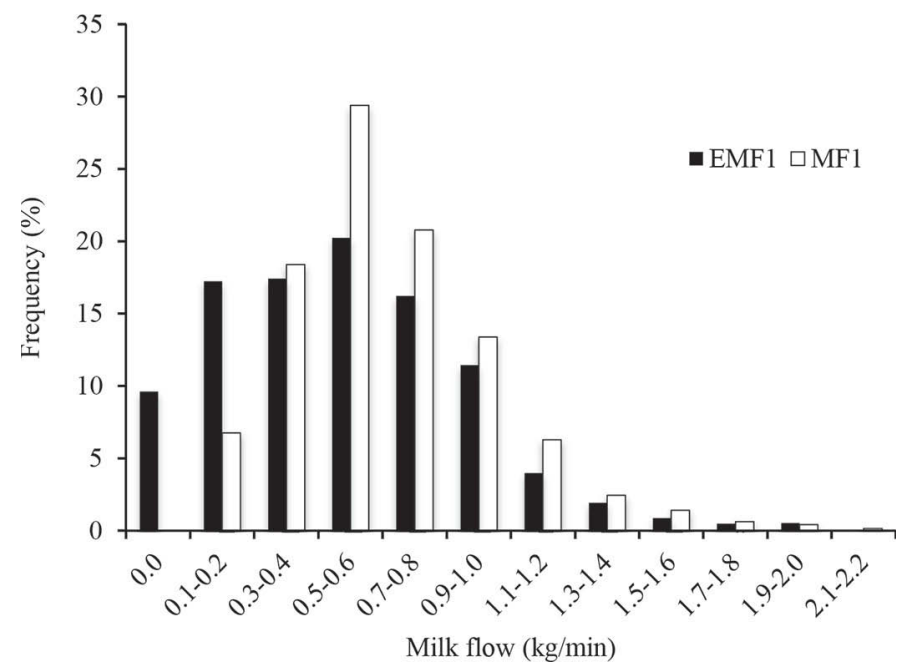

Figure 1. Frequency distribution of milk flow in first minute (MF1, $\mathrm{kg} / \mathrm{min} ; \mathrm{n}=2,497$ records) and estimated milk flow in first minute $(\mathrm{EMF} 1=2 \times \mathrm{MF} 0.5$, with MF0.5 being the milk flow over $30 \mathrm{~s} ; \mathrm{kg} /$ $\min ; \mathrm{n}=2,438$ records)

cy distribution was shifted to the left compared with MF1 (Figure 1, representing MF1 and $2 \times$ MF0.5). In this figure, it can be seen that $10 \%$ of the MF0.5 records had zero values, but this never occurred with MF1. This was because some goats did not produce any milk during the first $30 \mathrm{~s}$ after T0, but in all goats some milk was obtained during the first minute after T0. Figure 1 also shows that around $25 \%$ of the animals had very low milk flow (MF1 lower than $0.4 \mathrm{~kg} / \mathrm{min}$ ).

Mean values for total milk and fat and protein percentages were $1.97(0.75) \mathrm{kg}, 5.13 \mathrm{~g} / 100 \mathrm{~g}$ (1.14), and $3.77 \mathrm{~g} / 100 \mathrm{~g}$ (0.54), respectively. Arithmetic and geometric mean of SCC were $1,246 \times 10^{3}\left(2,403 \times 10^{3}\right)$ and $505 \times 10^{3}$ cells $/ \mathrm{mL}$, respectively. Of the samples, 37.2 and $16.4 \%$ had SCC above 750,000 and 1,750,000 cells/
mL, values applied by de Crémoux and Poutrel (2001) to discriminate between uninfected animals and animals infected by minor pathogens $(750,000$ cells $/ \mathrm{mL})$ and infected by major pathogens $(1,750,000$ cells $/ \mathrm{mL})$.

Table 2 shows repeatabilities and phenotypic correlations between studied variables. Among milk flow traits, MF1 had the highest repeatability value (0.68), and the following value was MF0.5 (0.62). Repeatability of T0 and $\mathrm{T} 1$ were lower than the previous ones (0.45 and 0.58 , respectively). Repeatability for TM and protein percentage were higher than fat percentage and $\log _{10}$ SCC. Phenotypic correlations of MF1 were very high and positive with MF0.5 $(0.90 ; P<0.001)$, moderate and negative with T0 $(-0.42 ; P<0.001)$, and high and negative with T1 $(-0.63 ; P<0.001)$. Correlations between MF1 and economic traits were medium and positive for TM, very low and negative for protein percentage, and close to 0 for fat percentage and $\log _{10} \mathrm{SCC}$ variables. Phenotypic correlation between $\mathrm{T} 0$ and $\mathrm{T} 1$ was $0.75(P<0.001)$ and phenotypic correlations between the other milking variables (T0, T1, and MF0.5) with milk production and composition traits (TM, fat and protein percentages, and $\log _{10} \mathrm{SCC}$ ) were very low $(-0.10$ to +0.16$)$.

The statistical analysis results showed that the herdday control effect was highly significant $(P<0.001)$ for all variables studied. Lactation number effect was also significant for all variables, except for $\mathrm{T} 0$ and protein percentage (Table 3 ). The T1 increased significantly from first and second lactation (with 15.1 and $14.7 \mathrm{~s}$ ) up to $19.4 \mathrm{~s}$ as of the sixth. The MF0.5 tended to fall off as the lactation number increased, with differences in the first 2 lactations $(0.31 \mathrm{~kg} / 30 \mathrm{~s})$ compared with the fifth and subsequent lactations $(0.22-0.27 \mathrm{~kg} / 30 \mathrm{~s})$. The MF1 also decreased as the lactation number increased, in such a way that the first 2 lactations $(0.69$

Table 1. Number of records (n), mean value, SD, minimum, and maximum value of the variables ${ }^{1}$

\begin{tabular}{lccccc}
\hline & \multicolumn{5}{c}{ Statistics } \\
\cline { 2 - 6 } Variable & $\mathrm{n}$ & Mean & $\mathrm{SD}$ & Minimum & Maximum \\
\hline $\mathrm{T} 0, \mathrm{~s}$ & 2,081 & 4.9 & 4.0 & 1 & 49 \\
$\mathrm{~T} 1, \mathrm{~s}$ & 2,057 & 15.8 & 10.0 & 2 & 90 \\
$\mathrm{MF} 0.5, \mathrm{~kg} / 30 \mathrm{~s}$ & 2,089 & 0.29 & 0.19 & 0 & 1.1 \\
$\mathrm{MF} 1, \mathrm{~kg} / \mathrm{min}$ & 2,136 & 0.67 & 0.33 & 0.1 & 2.1 \\
$\mathrm{TM}, \mathrm{kg}$ & 2,106 & 1.97 & 0.75 & 0.4 & 5.5 \\
Fat, g/100 g & 1,963 & 5.13 & 1.14 & 2.11 & 6.26 \\
Protein, g/100 g & 1,966 & 3.77 & 0.54 & 2.38 & 24,466 \\
SCC, $10^{3} \mathrm{cells} / \mathrm{mL}$ & 1,699 & 1,246 & 2,403 & 11 & 7.39 \\
$\log _{10} \mathrm{SCC}$ & 1,699 & 5.70 & 0.56 & 4.04 & \\
\hline
\end{tabular}

${ }^{1} \mathrm{~T} 0=$ time (seconds) from the attachment of teatcups to arrival of milk at the milk claw; T1 = time (seconds) from attachment of teatcups to arrival of milk at the milk jar; MF0.5 = milk yield $(\mathrm{kg})$ recorded in the milk meter $30 \mathrm{~s}$ after appearance of milk in the claw (T0); MF1 = milk yield $(\mathrm{kg}$ ) recorded in the milk meter $60 \mathrm{~s}$ after appearance of milk in the claw (T0); TM = total milk $(\mathrm{kg})$ in the milk meter (machine milk plus machine stripping milk); Fat $=$ fat percentage $(\mathrm{g} / 100 \mathrm{~g})$; Protein $=$ protein percentage $(\mathrm{g} / 100 \mathrm{~g})$. 
Table 2. Repeatability (r, SE in brackets) and phenotypic correlations (below diagonal) between the variables ${ }^{1}$

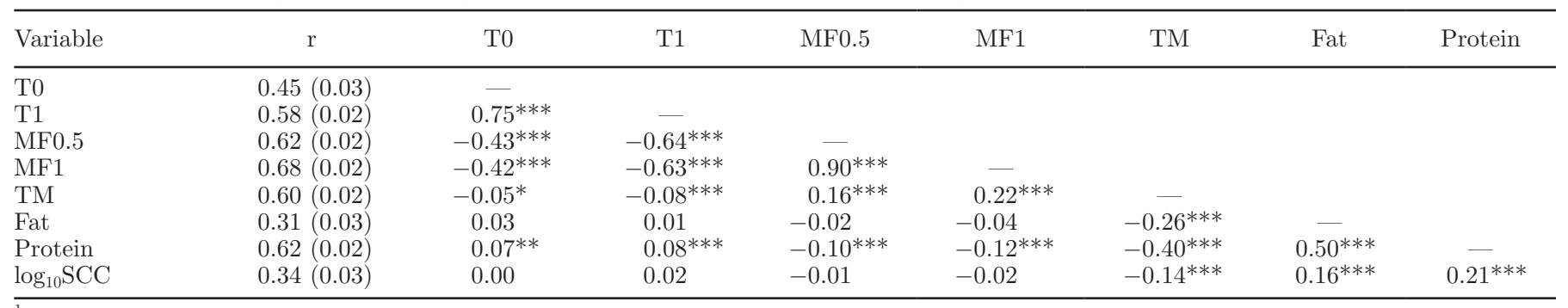

${ }^{1} \mathrm{~T} 0=$ time from the attachment of teatcups to arrival of milk at the milk claw; T1 = time from attachment of teatcups to arrival of milk at the milk jar; MF0.5 = milk yield recorded in the milk meter $30 \mathrm{~s}$ after appearance of milk in the claw $(\mathrm{T} 0) ; \mathrm{MF} 1=$ milk yield recorded in the milk meter $60 \mathrm{~s}$ after appearance of milk in the claw (T0); TM = total milk in the milk meter (machine milk plus machine stripping milk); Fat $=$ fat percentage; Protein $=$ protein percentage.

${ }^{*} P<0.05,{ }^{* *} P<0.01,{ }^{* * *} P<0.001$.

$0.71 \mathrm{~kg} / \mathrm{min})$ presented differences compared with the fifth $(0.63 \mathrm{~kg} / \mathrm{min})$, and even more so compared with the sixth and subsequent lactations $(0.54 \mathrm{~kg} / \mathrm{min})$. As we expected, TM in primiparous goats $(1.60 \mathrm{~kg})$ was lower than that obtained in multiparous goats $(2.07$ to $2.20 \mathrm{~kg}$ ). Fat percentage and $\log _{10}$ SCC increased significantly from first to third lactation, and did not vary significantly in subsequent lactations.

Month in milk did not affect T0, T1, and MF0.5, but did have a significant effect on the remaining variables (Table 4). The MF1 was diminished throughout lactation, going from 0.67 to $0.71 \mathrm{~kg} / \mathrm{min}$ in the first $3 \mathrm{mo}$ to $0.58-0.63 \mathrm{~kg} / \mathrm{min}$ as of the seventh month. The TM progressed as a lactation curve, with peak production values in the early months and a falloff from the fourth month until the end of lactation. As the lactation progressed, the composition variables varied inversely with production, with lows in the early months and peaks at the end of lactation. The $\log _{10}$ SCC also varied inversely in relation to production, with minimum values in the first $3 \mathrm{mo}$ and the highest values as of the fifth month (Table 4).

\section{DISCUSSION}

To compare the MF1 values with the literature, we must first specify the methodology. In our case, we began taking measurements from the moment the first streams of milk appeared in the claw (T0), whereas in other works measuring began immediately after the attachment of teatcups or when the first streams reached the meter (MF1r). From the mean value of MF1 in our experiment $(0.67 \mathrm{~kg} / \mathrm{min})$ and the mean latency time values obtained (T0: $4.9 \mathrm{~s}$; T1: $15.8 \mathrm{~s}$ ), we can estimate an approximate MF1r of $0.8 \mathrm{~kg} / \mathrm{min}$. This latter value is similar to the MF1r of 0.8 to $0.9 \mathrm{~kg} / \mathrm{min}$ obtained with electronic meters by Fernández et al. (2015) in Murciano-Granadina goats from an experimental station, with 1 daily milking and a $2 \mathrm{~L} / \mathrm{d}$ milk yield. In other research into this breed in experimental stations, notably lower MF1r values were obtained $(0.44 \mathrm{~kg} / \mathrm{min}$, Peris et al., 1996; $0.61 \mathrm{~kg} / \mathrm{min}$, Manzur et al., 2012), possibly because the animals used presented a lower average milk production $(0.5 \mathrm{~L}$ in the afternoon milking with 2 milkings daily and $1 \mathrm{~L}$ in single milking, respectively). The Murciano-Granadina breed could be considered to have a milk flow (in the first minute) similar to that of the Saanen breed (MF1r $0.72 \mathrm{~kg} / \mathrm{min}$, Marnet et al., 2005) and lower than those of the Alpine (MF1r $0.90 \mathrm{~kg} / \mathrm{min}$, Marnet et al., 2005) and Tinerfeña breeds (MF1r $1.06 \mathrm{~kg} / \mathrm{min}$, Capote et al., 2006).

The 2 latency time variables presented very different mean values (T0: $4.9 \mathrm{~s}$; T1: $15.8 \mathrm{~s}$ ), which can be explained because the milk meters used in the milking parlor were always located around $0.5 \mathrm{~m}$ above the animals standing level, regardless of whether the milk line was in a low- or in mid-level milking system. Thus, from T0 it was necessary for a certain quantity of milk to accumulate in the claw before gushing up through the long milk tube to reach the proportional milk meter. The fact that T1 was higher in mid-level (12 s) than in low-level (6 s) milking systems was already demonstrated by Díaz et al. (2004) in an experimental farm. Both T0 and T1 values in our work are slightly higher than those reported by Ilahi et al. (1999) in the Alpine breed (3.2 and $12.8 \mathrm{~s}$, respectively).

In the absence of electronic milk meters, the 3 variables T0, T1, and MF0.5 are recorded more quickly and, therefore, at a lower time-cost than MF1. For this reason, we studied these 3 variables as possible alternatives to characterize the milking speed in a goat population. Both T0 and T1 presented negative and moderate correlations with MF1 ( -0.42 and -0.63 , respectively), albeit slightly lower than those found by Ilahi et al. (1999; -0.45 and -0.75 , respectively). This may be because our work was carried out in several commercial herds, whose machine-milking conditions might have affected the milk flow traits, whereas the 


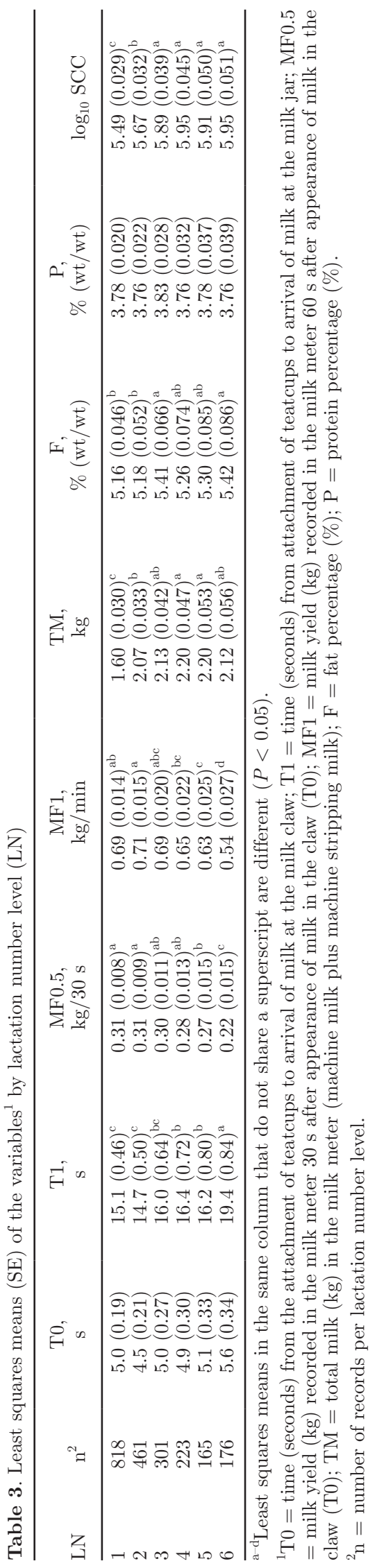

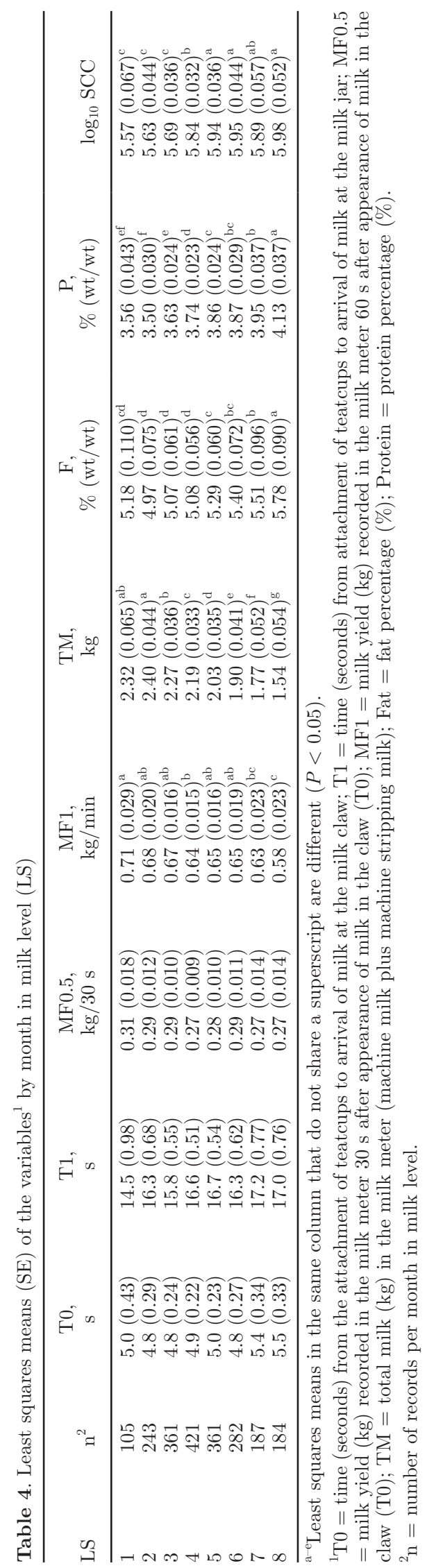


work by Ilahi et al. (1999) was performed in only 1 experimental herd. According to Marnet et al. (2005), these negative correlations suggest common biological mechanisms that regulate the start of milk emission and subsequent milk flow. The anatomical and physiological teat characteristics (sphincter resistance) are crucial for milk emission kinetics (Marnet et al., 2005). However, the results achieved did not suggest that MF1 should be replaced by any of the previously described variables, as the correlations of T0 and T1 with MF1 were moderate. Although MF0.5 had a high correlation with MF1 (0.90), it was handicapped by having zero value in $10 \%$ of the records, unlike MF1; moreover, these 3 traits show lower repeatability than MF1.

Milk production correlations with the flow variables (MF0.5 and MF1) were positive, indicating that more productive animals tended to have higher milk flows. However, these correlations were very low $(0.16$ and 0.22 ) and many of the animals had very low milk flows (less than $0.4 \mathrm{~kg} / \mathrm{min}$ ) and at the same time presented high milk production. These animals would be most problematic, as they take a long time to milk, but at the same time farmers are reluctant to remove them from the herd due to their high milk production output. These correlations presented values between 0.10 (Ilahi et al., 2000) and 0.25, estimated by Peris et al. (1996) and Ilahi et al. (1999)

Conversely, animals with a high milking speed might also be troublesome, as works in cattle have described how excessively high milk flows may increase mastitis rates and SCC (Grindal and Hillerton, 1991; Mielke, 1994; Rupp and Boichard, 1999); moreover, estimated genetic correlations between milk flows and SCC in Alpine and Saanen goats were positive (0.63 and 0.39, respectively; Palhière et al., 2014). However, we found virtually no phenotypic correlation between milk flow and $\log _{10}$ SCC, in accordance with the low phenotypic correlation (0.11, not significantly different from zero) reported by Marnet et al. (2005) in goats. It is possible that our result was due to several reasons: (a) the small number of animals showing very high flows (fewer than $2.5 \%$ of records with flows over $1.4 \mathrm{~kg} / \mathrm{min}$ ); (b) the existence of factors affecting the recording of milk flow from the same animal (for example, milking conditions or the amount of milk present in the udder during milking); or (c) several other factors influencing SCC in dairy goats, such as age, DIM, estrus, time of infection, or the pathogenic agent (Mehdid et al., 2013; Jiménez-Granado et al., 2014; Paterna et al., 2014). In any case, the existence of a positive genetic correlation between milk flow and SCC in high-yielding goats (Palhière et al., 2014) would indicate that the selection of animals with high flows would lead to deterioration in the health status of the udders. Thus, selection should not be done on high-milk flow animals but to eliminate animals whose milking flows are too low, which would reduce variability of this trait in herds.

The effect of lactation number and month in milk on milk flow found in this work is similar to that described in other studies (Ilahi et al., 1999; Marnet et al., 2005). In principle, these changes could be associated with variation in milk production and hence in intramammary pressure, or with changes in the anatomical and physiological characteristics of the teats. In the case of month in milk, the tendency to reduce milk flow as the months elapsed postpartum could be explained mainly by the reduction in intramammary pressure. Le Du et al. (1993) found that the teat sphincter resistance (vacuum needed for opening) scarcely varies throughout lactation, which would also explain why we found that this had no significant effect on latency times. In the case of lactation number, the tendency to diminish milk flow and increase $\mathrm{T} 1$ as of the third or fourth parity cannot be explained by changes in milk production, which scarcely varied among these goats. Thus, the trend may be due to changes in the teat wall and muscle tonicity throughout the productive life of the dairy goat (Chastin et al., 2000).

\section{CONCLUSIONS}

Results showed that MF1 was the trait of choice for estimating milk flow during milking because the other traits (T0, T1, and MF0.5), easily recorded, have lower repeatability than MF1 $(0.45,0.58$, and 0.62 , respectively, versus 0.68 ). For this reason, we considered that MF1 should continue to be used to estimate milk flow machine. First minute milk flow in Murciano-Granadina is intermediate, at $0.67 \mathrm{~kg} / \mathrm{min}$, with a difference of more than $2 \mathrm{~kg} / \mathrm{min}$ between the fastest and slowest. Milking speed analysis models in goats must include the herd, control day, lactation number, and lactation stage. It is necessary to characterize these traits economically and genetically and study their inclusion in dairy goat breeding programs. Currently, only milk production and composition traits are concerned. The aim is to try to reduce the variance in individual milking times and optimize work and energy saving.

\section{ACKNOWLEDGMENTS}

This work was funded by the Spanish INIA (Instituto Nacional de Investigación y Tecnología Agraria y Alimentaria, Madrid, Spain) through European FEDER funds (the project RTA2010-0132 led by E. A. Gomez and the scholarship FPI-INIA2011-042 attained by E. Blasco). In addition, the authors thank all AMURVAL 
breeders for their selfless disposition in hosting the experimental work.

\section{REFERENCES}

Bruckmaier, R. M., C. Ritter, D. Schams, and J. W. Blum. 1994 Machine milking of dairy goats during lactation: Udder anatomy, milking characteristics, and blood concentrations of oxytocin and prolactin. J. Dairy Res. 61:457-466.

Bueso-Ródenas, J., G. Romero, A. Roca, and J. R. Díaz. 2014. Effect of one automatic cluster remover (ACR) setting on milking efficiency on Murciano-Granadina goats. Livest. Sci. 161:193-200.

Capote, J., A. Argüello, N. Castro, J. L. López, and G. Caja. 2006 Short communication: Correlations between udder morphology, milk yield, and milking ability with different milking frequencies in dairy goats. J. Dairy Sci. 89:2076-2079.

Chastin, P., E. Ricard, J. Arhainxt, E. Manfredi, F. Bouvier, J. Martin, F. Monod, P. Lahaye, and P. Fourcaud. 2000. Variabilité génétique et facteurs de variation des caractéristiques de traite chez la chèvre. Pages 77-83 in La Cinétique D'émission du Lait et L'aptitude à la Traite Chez la Chèvre Aide au Paramètrage des Machines à Traire. Institut de l'Elevage, Paris, France.

de Crémoux, R., and B. Poutrel. 2001. Somatic cell count in goats milk: A tool in presumptive diagnosis of intramammary infections. Pages 757-760 in Proc. 7th International Conference on Goats, Tours, France. L. Gruner, and Y. Chabert, ed. Institut d'Elevage and INRA, Paris, France.

Díaz, J. R., C. Peris, M. Rodriguez, M. P. Molina, and N. Fernandez. 2004. Effect of milking pipeline height on machine milking efficiency and milk quality in sheep. J. Dairy Sci. 87:1675-1683.

FAO. 2013. FAOSTAT. Food and Agriculture Organization of the United Nations. Accessed June 2015. http://faostat.fao.org/ site/573/DesktopDefault.aspx?PageID=573\#ancor.

Fernández, N., A. Martínez, J. V. Martí, M. Rodríguez, and C. Peris. 2015. Milkability and milking efficiency improvement in MurcianoGranadina breed goats. Small Rumin. Res. 126:68-72.

Grindal, R. J., and J. E. Hillerton. 1991. Influence of milk flow rate on new intramammary infection in dairy cows. J. Dairy Res. 58:263268.

Ilahi, H., P. Chastin, F. Bouvier, J. Arhainx, E. Ricard, and E. Manfredi. 1999. Milking characteristics of dairy goats. Small Rumin. Res. 34:97-102.

Ilahi, H., P. Chastin, J. Martin, F. Mood, and E. Manfredi. 1998. Genetic association between milking speed and milk production. Pages 216-219 in Proc. 6th World Congr. Genet. Appl. Livest. Prod. (WCGALP), Armidale, Australia. Vol 24. University of New England, Armidale, NSW, Australia.

Ilahi, H., E. Manfredi, P. Chastin, F. Monod, J. M. Elsen, and P. Le Roy. 2000. Genetic variability in milking speed of dairy goats. Genet. Res. 75:315-319.
Jiménez-Granado, R., M. Sánchez-Rodríguez, C. Arce, and V. Rodríguez-Estévez. 2014. Factors affecting somatic cell count in dairy goats: A review. Span. J. Agric. Res. 12:133-150.

Komara, M., and P. G. Marnet. 2009. Endocrine responses and milk emission characteristics in high yielding Alpine dairy goats under once daily milking management. Small Rumin. Res. 87:64-69.

Le Du, J., G. Perrin, C. Baudry, and Y. Dano. 1993. Aptitude of Alpine breed goats for machine milking. Incidence of teat canal elasticity. Pages 31-37 in Proc. 5th International Symposium on Machine Milking of Small Ruminants, Budapest, Hungary. S. Kukovics, ed. Hungary.

Manzur, A., J. R. Díaz, A. Mehdid, N. Fernández, and C. Peris. 2012. Effect of mid-line or low-line milking systems on milking characteristics in goats. J. Dairy Res. 79:375-382.

Marnet, P. G., P. Billon, E. Sinapsis, P. Da Ponte, and E. Manfredi. 2005. Machine milking ability in goats: Genetic variability and physiological basis of milk flow rate. Pages 15-24 in ICAR Technical Series No. 10. ICAR, Rome, Italy.

Marnet, P. G., and B. C. McKusick. 2001. Regulation of milk ejection and milkability in small ruminants. Livest. Prod. Sci. 70:125-133.

Mehdid, A., J. R. Díaz, A. Martí, G. Vidal, and C. Peris. 2013. Effect of estrus synchronization on daily somatic cell count variation in goats according to lactation number and udder health status. J. Dairy Sci. 96:4368-4374.

Mielke, H. 1994. Physiologie der Laktation. Pages 64-114 in Euterund Gesäugekrankheiten. K. Wendt, H. Bostedt, H. Mielke, and H. W. Fuchs, ed. Gustav Fischer Verlag, Jena, Germany.

MURCIGRAN. 2015. Federación Española de Criadores de Caprino de Raza Murciano-Granadina Accessed June 2015. http://www. murcigran.es.

Palhière, I., H. Larroque, V. Clément, G. Tosser-Klopp, and R. Rupp. 2014. Genetic parameters and QTL detection for milking speed in dairy Alpine and Saanen goats. Page 892 in Proc. 10th World Congr. Genet. Appl. Livest. Prod. (WCGALP), Vancouver, Canada. American Society of Animal Science, Champaign, IL.

Paterna, A., A. Contreras, A. Gómez-Martin, J. Amores, J. TatayDualde, M. Prats-van der Ham, J. C. Corrales, A. Sánchez, and C. de la Fe. 2014. The diagnosis of mastitis and contagious agalactia in dairy goats. Small Rumin. Res. 121:36-41.

Peris, S., X. Such, and G. Caja. 1996. Milkability of Murciano-Granadina dairy goats. Milk partitioning and flow rate during machine milking according to parity, prolificacy and mode of suckling. J. Dairy Res. 63:1-9.

Ricordeau, G., J. Bouillon, P. Leroy, and J. M. Elsen. 1990. Genetic of milk flow in Alpine and Saanen goats. Prod. Anim. 3:121-126.

Rupp, R., and D. Boichard. 1999. Genetic parameters for clinical mastitis, somatic cell score, production, udder type traits, and milking ease in first lactation Holsteins. J. Dairy Sci. 82:2198-2204. 